Supporting Information on

\title{
Divergent Optical Properties in an Isomorphous Family of Multinary lodido Pentelates
}

Natalie Dehnhardt†, Philip Klement $¥$, Sangam Chatterjeeł, Johanna Heinet*

† Department of Chemistry and Material Sciences Center, Philipps-Universität Marburg, Hans-Meerwein-Straße, 35043 Marburg, Germany.

¥ Institute of Experimental Physics I and Center for Materials Research (ZfM), Justus Liebig University Giessen, Giessen, Germany

*E-Mail: johanna.heine@chemie.uni-marburg.de 


\section{Crystallographic Details}

Single crystal X-ray determination was performed on a STOE IPDS2 diffractometer equipped with an imaging plate detector system using MoK $\alpha$ radiation with graphite monochromatization $(\mathbf{1}, \mathbf{4})$ or on a Bruker Quest D8 diffractometer with microfocus MoKa radiation and a Photon 100 (CMOS) detector $(2,3)$.

Table S1: Crystallographic data for $\left[\mathrm{PPh}_{4}\right]_{2}\left[\mathrm{SbCu}_{2} \mathrm{I}_{7}\left(\mathrm{CH}_{3} \mathrm{CN}\right)\right](\mathbf{1})$.

\begin{tabular}{|c|c|}
\hline Empirical formula & $\mathrm{C}_{50} \mathrm{H}_{43} \mathrm{Cu}_{2} \mathrm{I}_{7} \mathrm{NP}_{2} \mathrm{Sb}$ \\
\hline Formula weight & 1856.92 \\
\hline Temperature/K & 100.0 \\
\hline Crystal system & monoclinic \\
\hline Space group & $C c$ \\
\hline $\mathrm{a} / \AA$ & $19.5958(8)$ \\
\hline $\mathrm{b} / \AA \AA$ & $17.2708(5)$ \\
\hline $\mathrm{c} / \AA$ & $16.7887(8)$ \\
\hline$\alpha /{ }^{\circ}$ & 90 \\
\hline$\beta /{ }^{\circ}$ & $103.833(3)$ \\
\hline$\gamma /{ }^{\circ}$ & 90 \\
\hline Volume $/ \AA^{3}$ & $5517.1(4)$ \\
\hline $\mathrm{Z}$ & 4 \\
\hline$\rho_{\text {calc }} \mathrm{g} / \mathrm{cm}^{3}$ & 2.236 \\
\hline$\mu / \mathrm{mm}^{-1}$ & 5.259 \\
\hline $\mathrm{F}(000)$ & 3440.0 \\
\hline Crystal size $/ \mathrm{mm}^{3}$ & $0.22 \times 0.182 \times 0.118$ \\
\hline Absorption correction $\left(\mathrm{T}_{\min } / \mathrm{T}_{\max }\right)$ & analytical $(0.2290 / 0.4637)$ \\
\hline $2 \Theta$ range for data collection $/^{\circ}$ & 3.718 to 63.854 \\
\hline Index ranges & $-28 \leq \mathrm{h} \leq 28,-25 \leq \mathrm{k} \leq 25,-21 \leq 1 \leq 24$ \\
\hline Reflections collected & 35374 \\
\hline Independent reflections & $16822\left[\mathrm{R}_{\mathrm{int}}=0.0512, \mathrm{R}_{\text {sigma }}=0.0740\right]$ \\
\hline Data/restraints/parameters & $16822 / 2 / 579$ \\
\hline Goodness-of-fit on $\mathrm{F}^{2}$ & 0.840 \\
\hline Final $R$ indexes $[\mathrm{I}>=2 \sigma(\mathrm{I})]$ & $\mathrm{R}_{1}=0.0311, \mathrm{wR}_{2}=0.0638$ \\
\hline Final $\mathrm{R}$ indexes [all data] & $\mathrm{R}_{1}=0.0416, \mathrm{wR}_{2}=0.0653$ \\
\hline Largest diff. peak/hole / e $\AA^{-3}$ & $1.66 /-1.33$ \\
\hline Flack parameter & $-0.02(2)$ \\
\hline
\end{tabular}

Details of crystal structure refinement: All non-hydrogen atoms were refined anisotropically. Hydrogen atoms were assigned to idealized geometric positions and included in structure factors calculations. One copper atom was disordered over two positions with occupancies 0.3 and 0.7 for Cu1A and Cu1B, respectively. Occupancies were first refined freely, then set to an appropriate value to stabilize the refinement. 


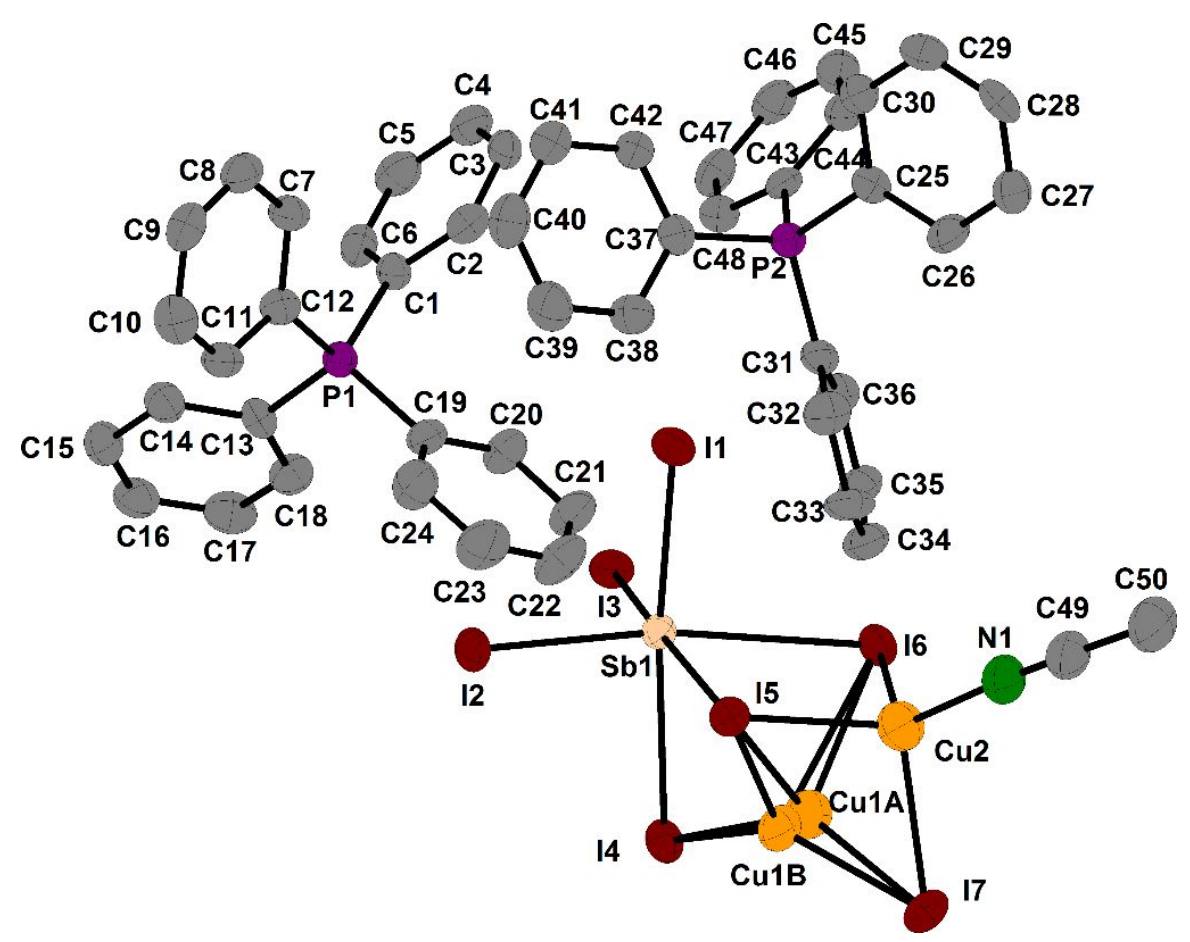

Figure S1: Asymmetric unit of 1, ellipsoids at $80 \%$ probability. 
Table S2: Crystallographic data for $\left[\mathrm{PPh}_{4}\right]_{2}\left[\mathrm{SbCu}_{2} \mathrm{I}_{7}\left(\mathrm{CH}_{3} \mathrm{CH}_{2} \mathrm{CN}\right)\right]$ (2).

\begin{tabular}{|c|c|}
\hline Empirical formula & $\mathrm{C}_{51} \mathrm{H}_{45} \mathrm{Cu}_{2} \mathrm{I}_{7} \mathrm{NP}_{2} \mathrm{Sb}$ \\
\hline Formula weight & 1870.95 \\
\hline Temperature/K & 105.01 \\
\hline Crystal system & monoclinic \\
\hline Space group & $C c$ \\
\hline $\mathrm{a} / \AA$ & $19.7444(8)$ \\
\hline $\mathrm{b} / \AA$ & $17.4660(7)$ \\
\hline $\mathrm{c} / \AA$ & $16.9029(7)$ \\
\hline$\alpha /^{\circ}$ & 90 \\
\hline$\beta /{ }^{\circ}$ & $104.0120(10)$ \\
\hline$\gamma /{ }^{\circ}$ & 90 \\
\hline Volume $/ \AA^{3}$ & $5655.6(4)$ \\
\hline $\mathrm{Z}$ & 4 \\
\hline$\rho_{\text {calc }} \mathrm{g} / \mathrm{cm}^{3}$ & 2.197 \\
\hline$\mu / \mathrm{mm}^{-1}$ & 5.131 \\
\hline $\mathrm{F}(000)$ & 3472.0 \\
\hline Crystal size $/ \mathrm{mm}^{3}$ & $0.236 \times 0.185 \times 0.06$ \\
\hline Absorption correction $\left(\mathrm{T}_{\min } / \mathrm{T}_{\max }\right)$ & multi-scan $(0.5851 / 0.7452)$ \\
\hline $2 \Theta$ range for data collection $/^{\circ}$ & 4.252 to 50.636 \\
\hline Index ranges & $-23 \leq \mathrm{h} \leq 23,-20 \leq \mathrm{k} \leq 19,-20 \leq 1 \leq 20$ \\
\hline Reflections collected & 82962 \\
\hline Independent reflections & $10288\left[\mathrm{R}_{\mathrm{int}}=0.0389, \mathrm{R}_{\mathrm{sigma}}=0.0207\right]$ \\
\hline Data/restraints/parameters & $10288 / 2 / 575$ \\
\hline Goodness-of-fit on $\mathrm{F}^{2}$ & 1.075 \\
\hline Final $\mathrm{R}$ indexes $[\mathrm{I}>=2 \sigma(\mathrm{I})]$ & $\mathrm{R}_{1}=0.0149, \mathrm{wR}_{2}=0.0291$ \\
\hline Final $\mathrm{R}$ indexes [all data] & $\mathrm{R}_{1}=0.0164, \mathrm{wR}_{2}=0.0295$ \\
\hline Largest diff. peak/hole / e $\AA^{-3}$ & $0.67 /-0.85$ \\
\hline Flack parameter & $0.000(6)$ \\
\hline
\end{tabular}

Details of crystal structure refinement: All non-hydrogen atoms were refined anisotropically with the exception of a disordered copper atom and the propionitrile ligand. Hydrogen atoms were assigned to idealized geometric positions and included in structure factors calculations. Occupancies in the disordered parts of the structure were first refined freely, then set to an appropriate value to stabilize the refinement. Despite their proximity, the disorder in the copper atom and proprionitrile ligand occurs independent of each other, as indicated by different occupancies $(0.15$ and 0.85 for $\mathrm{Cu} 1 \mathrm{~A}$ and $\mathrm{Cu} 1 \mathrm{~B}$, and 0.7 and 0.3 for N1A, etc. and N1B, etc., respectively ). 


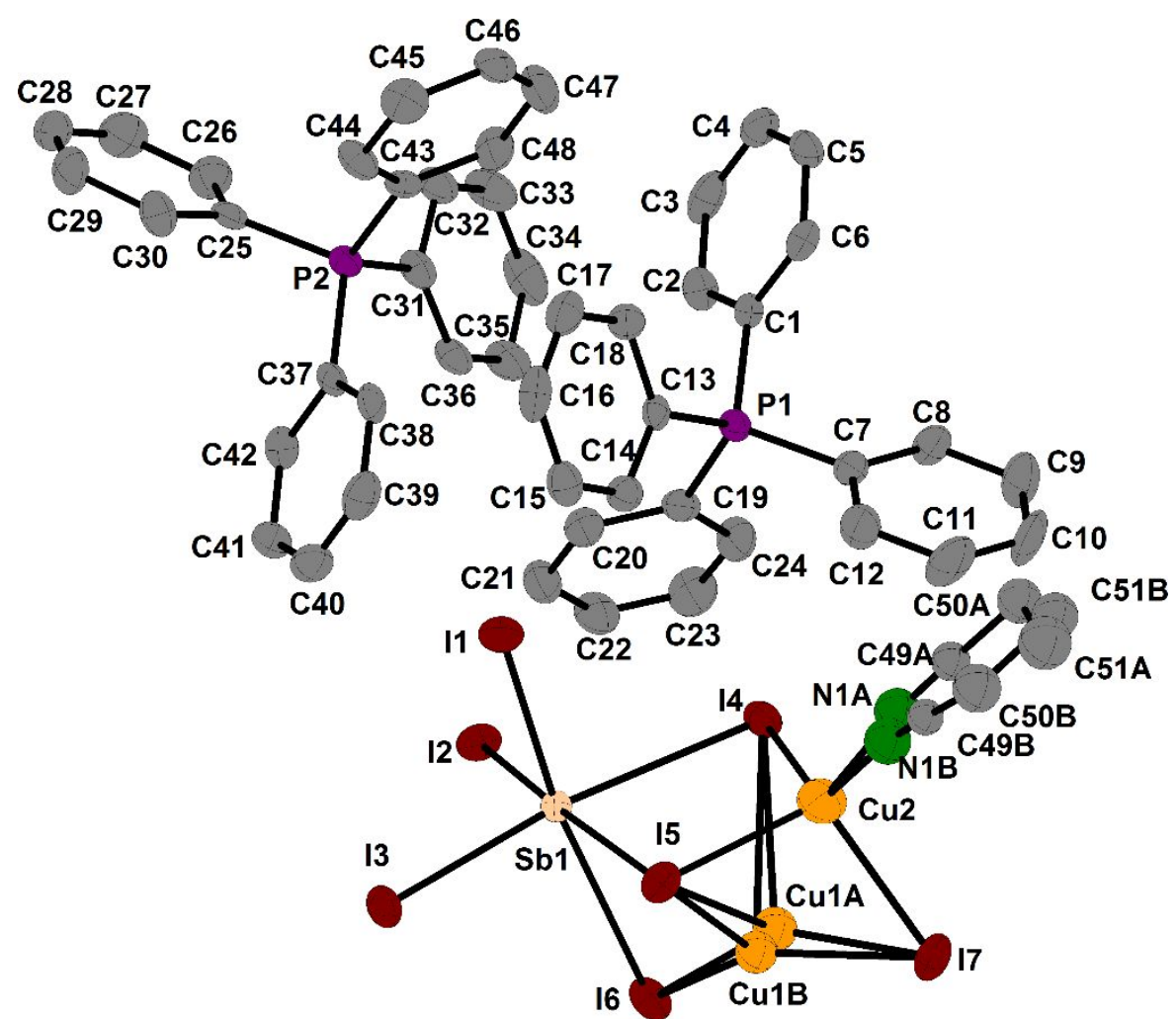

Figure S2: Asymmetric unit of 2, ellipsoids at $80 \%$ probability. 
Table S3: Crystallographic data for $\left[\mathrm{PPh}_{4}\right]_{2}\left[\mathrm{BiCu}_{2} \mathrm{I}_{7}\left(\mathrm{CH}_{3} \mathrm{CN}\right)\right]$ (3).

\begin{tabular}{|c|c|}
\hline Empirical formula & $\mathrm{C}_{50} \mathrm{H}_{43} \mathrm{BiCu}_{2} \mathrm{I}_{7} \mathrm{NP}_{2}$ \\
\hline Formula weight & 1944.26 \\
\hline Temperature/K & 100.01 \\
\hline Crystal system & monoclinic \\
\hline Space group & $C c$ \\
\hline $\mathrm{a} / \AA$ & $19.6722(9)$ \\
\hline $\mathrm{b} / \AA$ & $17.3553(8)$ \\
\hline $\mathrm{c} / \AA$ & $16.8568(8)$ \\
\hline$\alpha /^{\circ}$ & 90 \\
\hline$\beta /{ }^{\circ}$ & $103.836(2)$ \\
\hline$\gamma /{ }^{\circ}$ & 90 \\
\hline Volume $/ \AA^{3}$ & $5588.2(5)$ \\
\hline $\mathrm{Z}$ & 4 \\
\hline$\rho_{\text {calc }} \mathrm{g} / \mathrm{cm}^{3}$ & 2.311 \\
\hline$\mu / \mathrm{mm}^{-1}$ & 7.853 \\
\hline $\mathrm{F}(000)$ & 3568.0 \\
\hline Crystal size $/ \mathrm{mm}^{3}$ & $0.304 \times 0.22 \times 0.088$ \\
\hline Absorption correction $\left(\mathrm{T}_{\min } / \mathrm{T}_{\max }\right)$ & multi-scan $(0.4737 / 0.7452)$ \\
\hline $2 \Theta$ range for data collection $/{ }^{\circ}$ & 4.264 to 50.65 \\
\hline Index ranges & $-23 \leq \mathrm{h} \leq 23,-20 \leq \mathrm{k} \leq 20,-20 \leq 1 \leq 20$ \\
\hline Reflections collected & 79340 \\
\hline Independent reflections & $9832\left[\mathrm{R}_{\text {int }}=0.0349, \mathrm{R}_{\text {sigma }}=0.0328\right]$ \\
\hline Data/restraints/parameters & $9832 / 2 / 579$ \\
\hline Goodness-of-fit on $\mathrm{F}^{2}$ & 0.918 \\
\hline Final $\mathrm{R}$ indexes $[\mathrm{I}>=2 \sigma(\mathrm{I})]$ & $\mathrm{R}_{1}=0.0142, \mathrm{wR}_{2}=0.0313$ \\
\hline Final $\mathrm{R}$ indexes [all data] & $\mathrm{R}_{1}=0.0148, \mathrm{wR}_{2}=0.0315$ \\
\hline Largest diff. peak/hole / e $\AA^{-3}$ & $0.49 /-0.71$ \\
\hline Flack parameter & $0.0136(16)$ \\
\hline
\end{tabular}

Details of crystal structure refinement: All non-hydrogen atoms were refined anisotropically. Hydrogen atoms were assigned to idealized geometric positions and included in structure factors calculations. One copper atom was disordered over two positions with occupancies 0.25 and 0.75 for Cu1A and Cu1B, respectively. Occupancies were first refined freely, then set to an appropriate value to stabilize the refinement. 


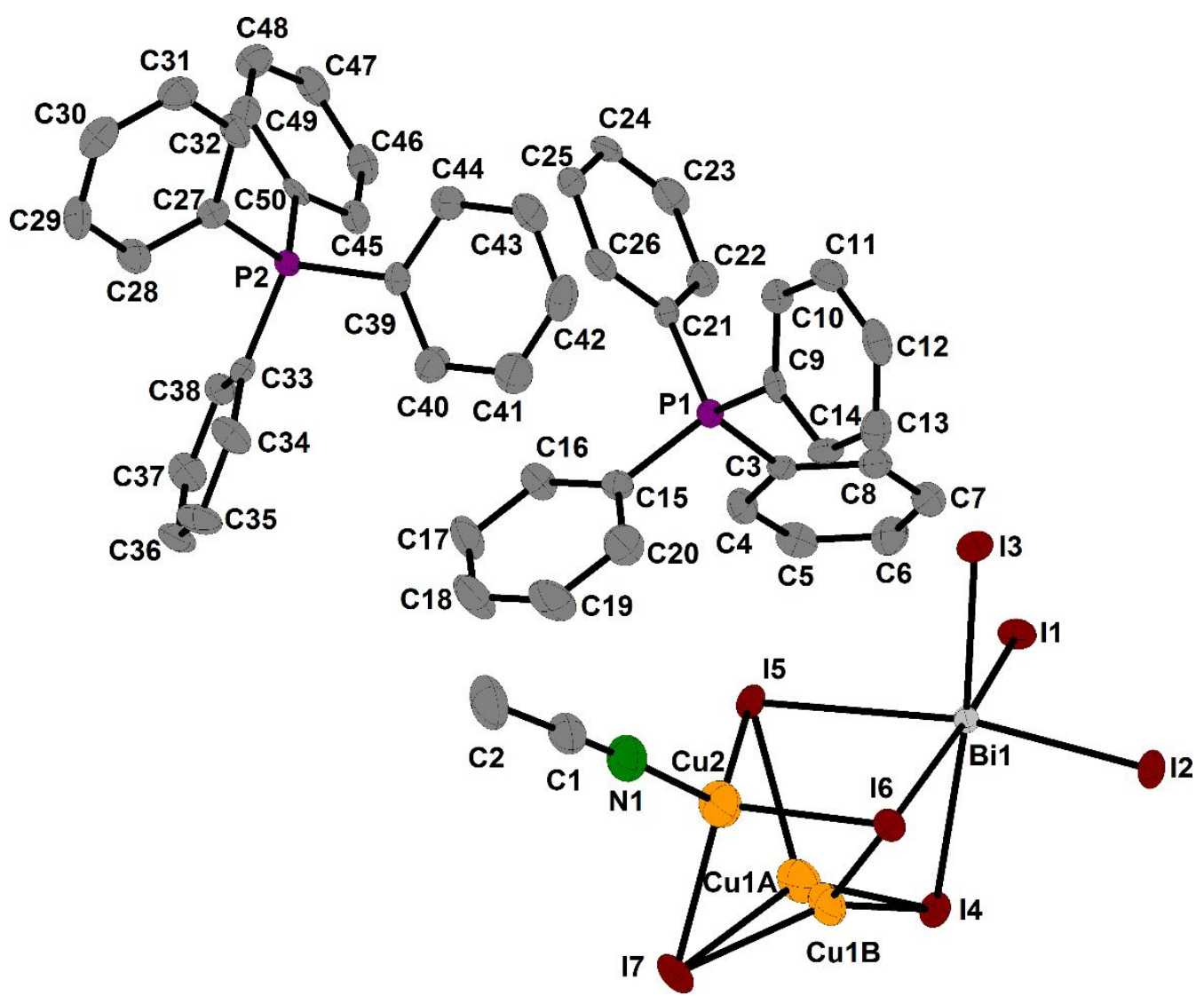

Figure S3: Asymmetric unit of 3, ellipsoids at $80 \%$ probability. 
Table S4: Crystallographic data for $\left[\mathrm{PPh}_{4}\right]_{2}\left[\mathrm{BiCu}_{2} \mathrm{I}_{7}\left(\mathrm{CH}_{3} \mathrm{CH}_{2} \mathrm{CN}\right)\right]$ (4).

\begin{tabular}{|c|c|}
\hline Empirical formula & $\mathrm{C}_{51} \mathrm{H}_{45} \mathrm{BiCu}_{2} \mathrm{I}_{7} \mathrm{NP}_{2}$ \\
\hline Formula weight & 1958.18 \\
\hline Temperature/K & 100.0 \\
\hline Crystal system & monoclinic \\
\hline Space group & $C c$ \\
\hline $\mathrm{a} / \AA$ & $19.6427(7)$ \\
\hline $\mathrm{b} / \AA$ & $17.5050(4)$ \\
\hline $\mathrm{c} / \AA ̊$ & $16.8610(5)$ \\
\hline$\alpha /{ }^{\circ}$ & 90 \\
\hline$\beta /{ }^{\circ}$ & $104.022(3)$ \\
\hline$\gamma /{ }^{\circ}$ & 90 \\
\hline Volume $/ \AA^{3}$ & $5624.8(3)$ \\
\hline Z & 4 \\
\hline$\rho_{\text {calc }} \mathrm{g} / \mathrm{cm}^{3}$ & 2.312 \\
\hline$\mu / \mathrm{mm}^{-1}$ & 7.803 \\
\hline $\mathrm{F}(000)$ & 3600.0 \\
\hline Crystal size $/ \mathrm{mm}^{3}$ & $0.578 \times 0.471 \times 0.222$ \\
\hline Absorption correction $\left(\mathrm{T}_{\min } / \mathrm{T}_{\max }\right)$ & analytical $(0.0476 / 0.2312)$ \\
\hline $2 \Theta$ range for data collection $/{ }^{\circ}$ & 3.688 to 63.814 \\
\hline Index ranges & $-29 \leq \mathrm{h} \leq 29,-25 \leq \mathrm{k} \leq 26,-23 \leq 1 \leq 25$ \\
\hline Reflections collected & 66513 \\
\hline Independent reflections & $18208\left[\mathrm{R}_{\mathrm{int}}=0.0415, \mathrm{R}_{\text {sigma }}=0.0354\right]$ \\
\hline Data/restraints/parameters & $18208 / 2 / 579$ \\
\hline Goodness-of-fit on $\mathrm{F}^{2}$ & 1.017 \\
\hline Final $R$ indexes $[\mathrm{I}>=2 \sigma(\mathrm{I})]$ & $\mathrm{R}_{1}=0.0310, \mathrm{wR}_{2}=0.0742$ \\
\hline Final R indexes [all data] & $\mathrm{R}_{1}=0.0344, \mathrm{wR}_{2}=0.0751$ \\
\hline Largest diff. peak/hole / e $\AA^{-3}$ & $3.60 /-1.65$ \\
\hline Flack parameter & $-0.024(3)$ \\
\hline
\end{tabular}

Details of crystal structure refinement: All non-hydrogen atoms were refined anisotropically. Hydrogen atoms were assigned to idealized geometric positions and included in structure factors calculations. 


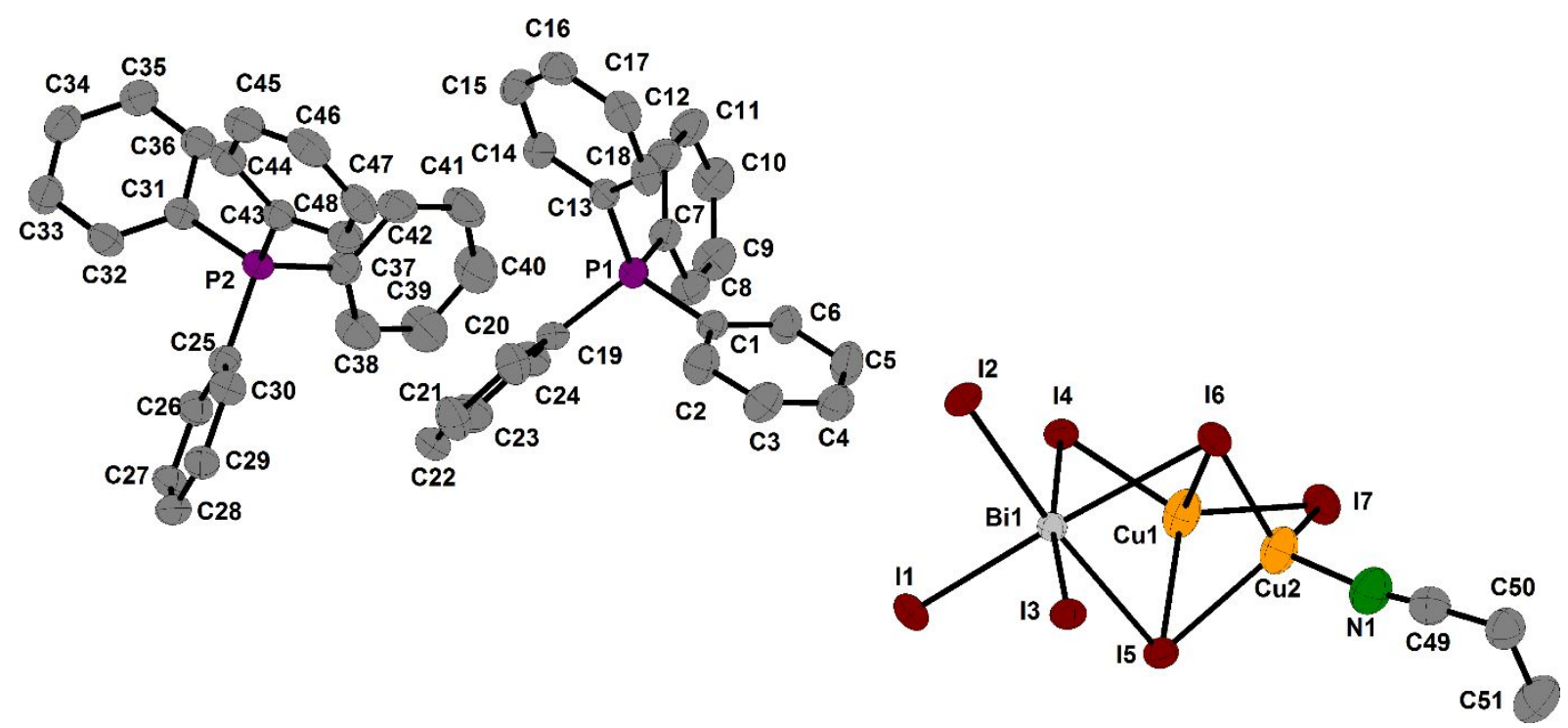

Figure S4: Asymmetric unit of 4 , ellipsoids at $80 \%$ probability.

Additional Crystallographic Figures

Majority

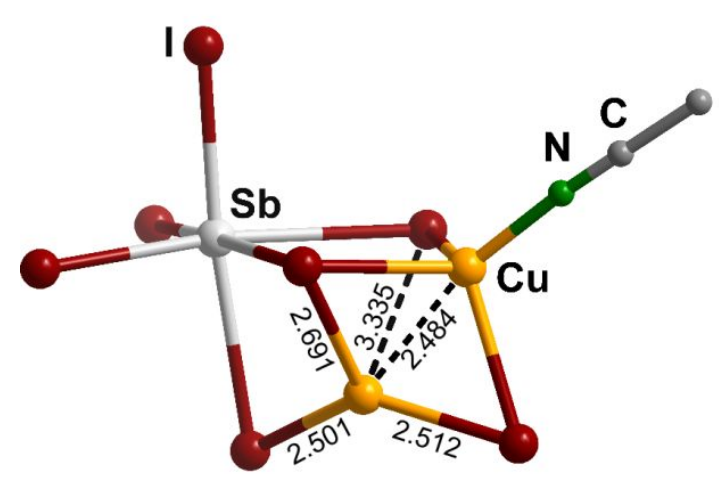

Minority

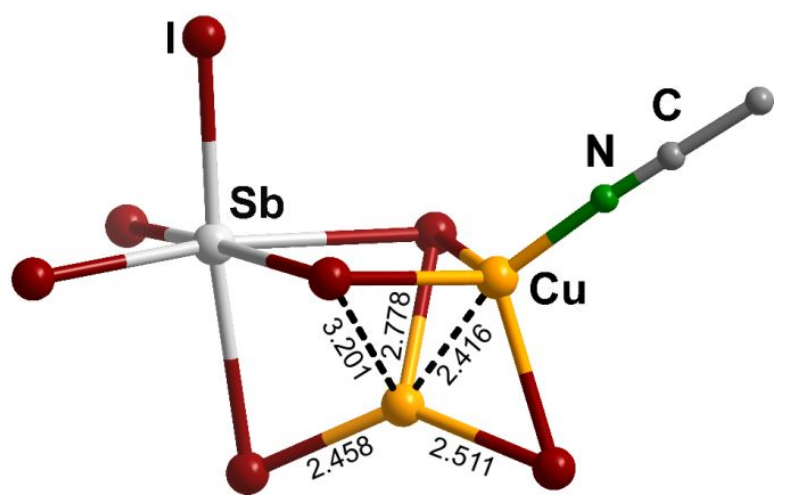

Figure S5: Bond and contact length in $\AA$ about the disordered $\mathrm{Cu}$ atom positions in $\left[\mathrm{PPh}_{4}\right]_{2}\left[\mathrm{SbCu}_{2} \mathrm{I}_{7}\left(\mathrm{CH}_{3} \mathrm{CN}\right)\right](1)$ for the majority and minority component. 


\section{Thermal analysis}

The thermal behavior of $\left[\mathrm{PPh}_{4}\right]_{2}\left[\mathrm{SbCu}_{2} \mathrm{l}_{7}\left(\mathrm{CH}_{3} \mathrm{CN}\right)\right](\mathbf{1})(12.5 \mathrm{mg})$, was studied on a Netzsch STA $409 \mathrm{CD}$ from 25 to $1200{ }^{\circ} \mathrm{C}$ with a heating rate of $10^{\circ} \mathrm{C} \mathrm{min}^{-1}$ in a constant flow of 150 $\mathrm{mL} \min ^{-1} \mathrm{Ar}$.

A mass loss of $2 \%$, corresponding to the loss of the acetonitrile ligand, can be observed starting at $167{ }^{\circ} \mathrm{C}$, followed by a mass loss of $71 \%$ starting at $310^{\circ} \mathrm{C}$. A third mass loss of $11 \%$ can be observed starting at $750{ }^{\circ} \mathrm{C}$.

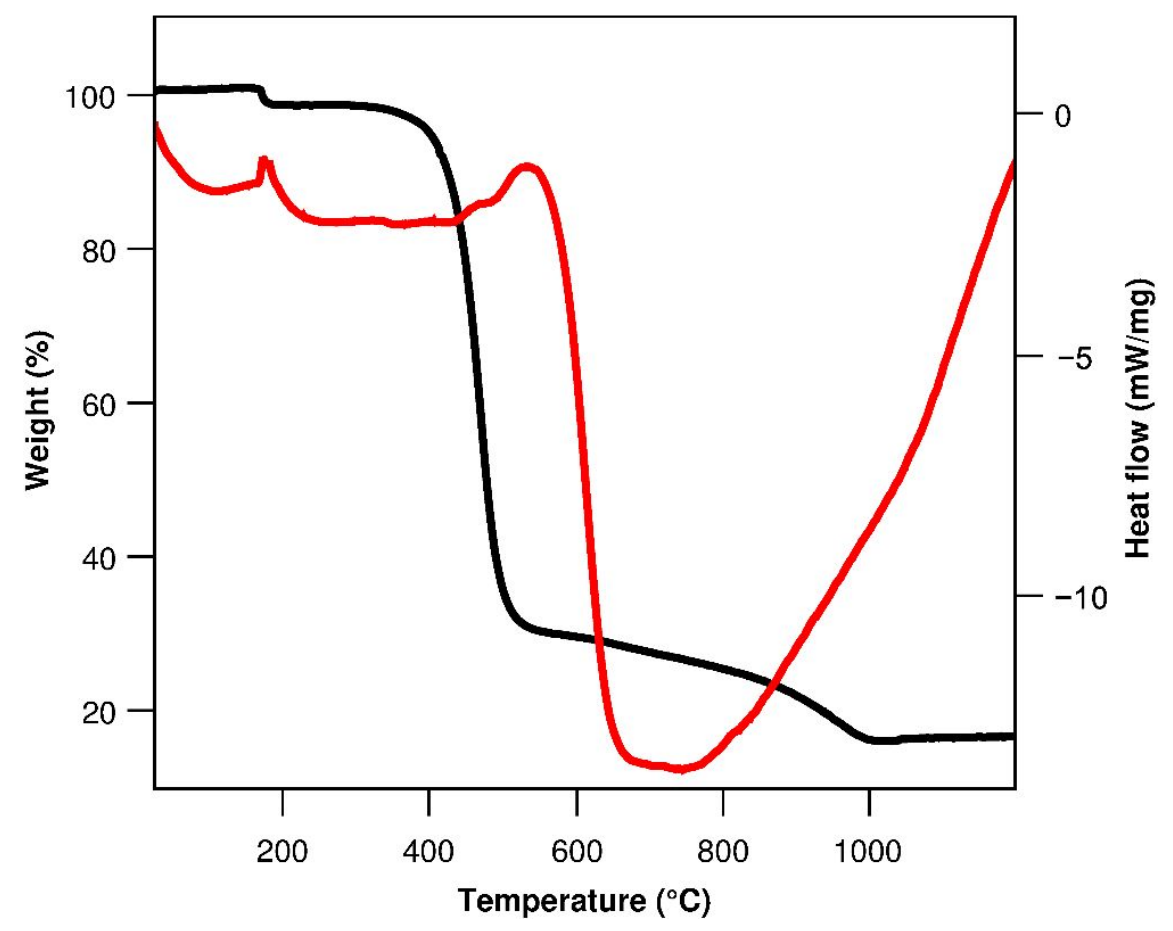

Figure S6. TGA and DSC of $\left[\mathrm{PPh}_{4}\right]_{2}\left[\mathrm{SbCu}_{2} \mathrm{I}_{7}\left(\mathrm{CH}_{3} \mathrm{CN}\right)\right](\mathbf{1})$. 
The thermal behavior of $\left[\mathrm{PPh}_{4}\right]_{2}\left[\mathrm{SbCu}_{2} \mathrm{I}_{7}\left(\mathrm{CH}_{3} \mathrm{CH}_{2} \mathrm{CN}\right)\right](2)(13.1 \mathrm{mg})$, was studied on a Netzsch STA $409 \mathrm{CD}$ from 25 to $1200{ }^{\circ} \mathrm{C}$ with a heating rate of $10^{\circ} \mathrm{C} \mathrm{min}^{-1}$ in a constant flow of 150 $\mathrm{mL} \min ^{-1} \mathrm{Ar}$.

A mass loss of $3 \%$, corresponding to the loss of the propionitrile ligand, can be observed starting at $160{ }^{\circ} \mathrm{C}$, followed by a mass loss of $71 \%$ starting at $310^{\circ} \mathrm{C}$. A third mass loss of 14 $\%$ can be observed starting at $750{ }^{\circ} \mathrm{C}$.

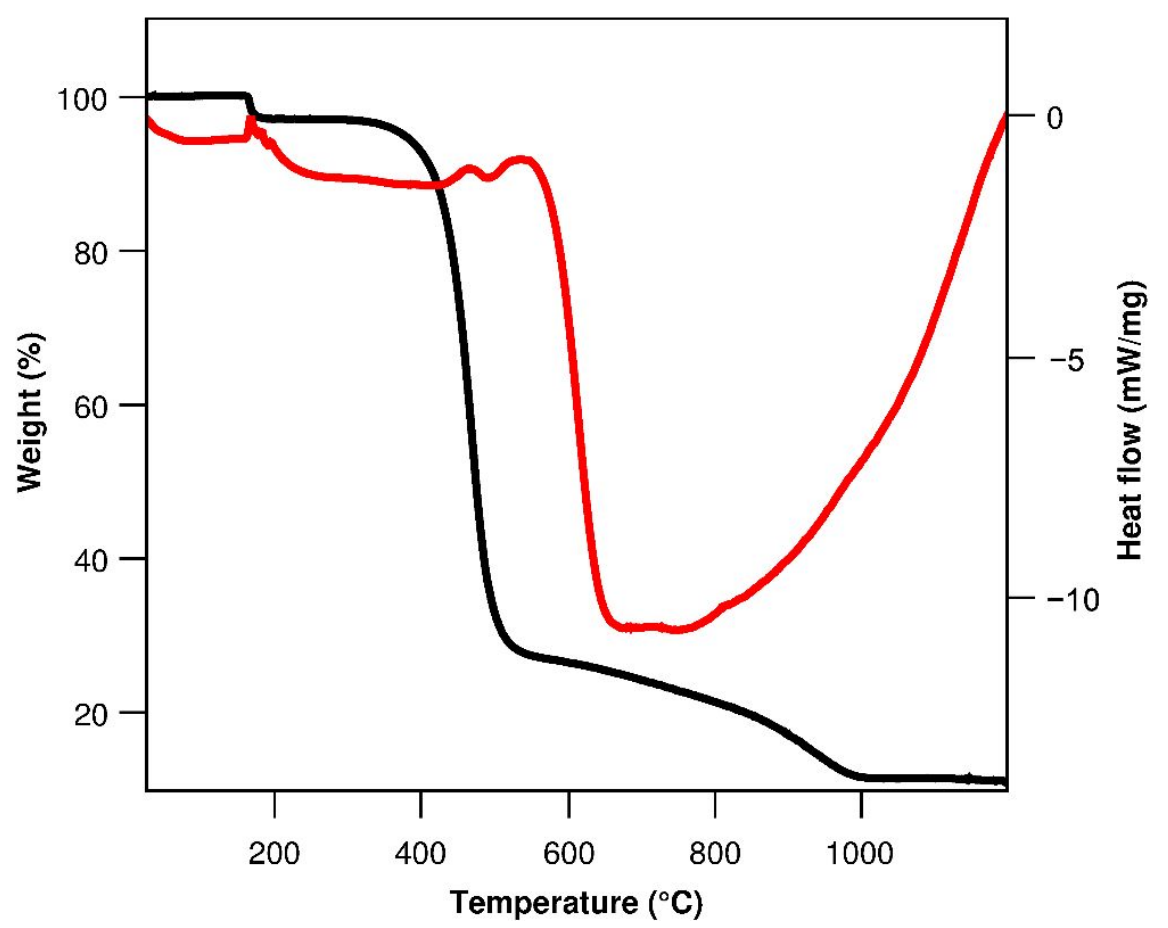

Figure S7. TGA and DSC of $\left[\mathrm{PPh}_{4}\right]_{2}\left[\mathrm{SbCu}_{2} \mathrm{I}_{7}\left(\mathrm{CH}_{3} \mathrm{CH}_{2} \mathrm{CN}\right)\right](2)$. 
The thermal behavior of $\left[\mathrm{PPh}_{4}\right]_{2}\left[\mathrm{BiCu}_{2} \mathrm{l}_{7}\left(\mathrm{CH}_{3} \mathrm{CN}\right)\right](3)(12.0 \mathrm{mg})$, was studied by TGA on a Netzsch STA $409 \mathrm{CD}$ from 25 to $1200{ }^{\circ} \mathrm{C}$ with a heating rate of $10{ }^{\circ} \mathrm{C} \mathrm{min}^{-1}$ in a constant flow of $150 \mathrm{~mL} \mathrm{~min}^{-1} \mathrm{Ar}$.

A mass loss of $2 \%$, corresponding to the loss of the acetonitrile ligand, can be observed starting at $175{ }^{\circ} \mathrm{C}$, followed by a mass loss of $71 \%$ starting at $380{ }^{\circ} \mathrm{C}$. A third mass loss of $12 \%$ can be observed starting at $750{ }^{\circ} \mathrm{C}$.

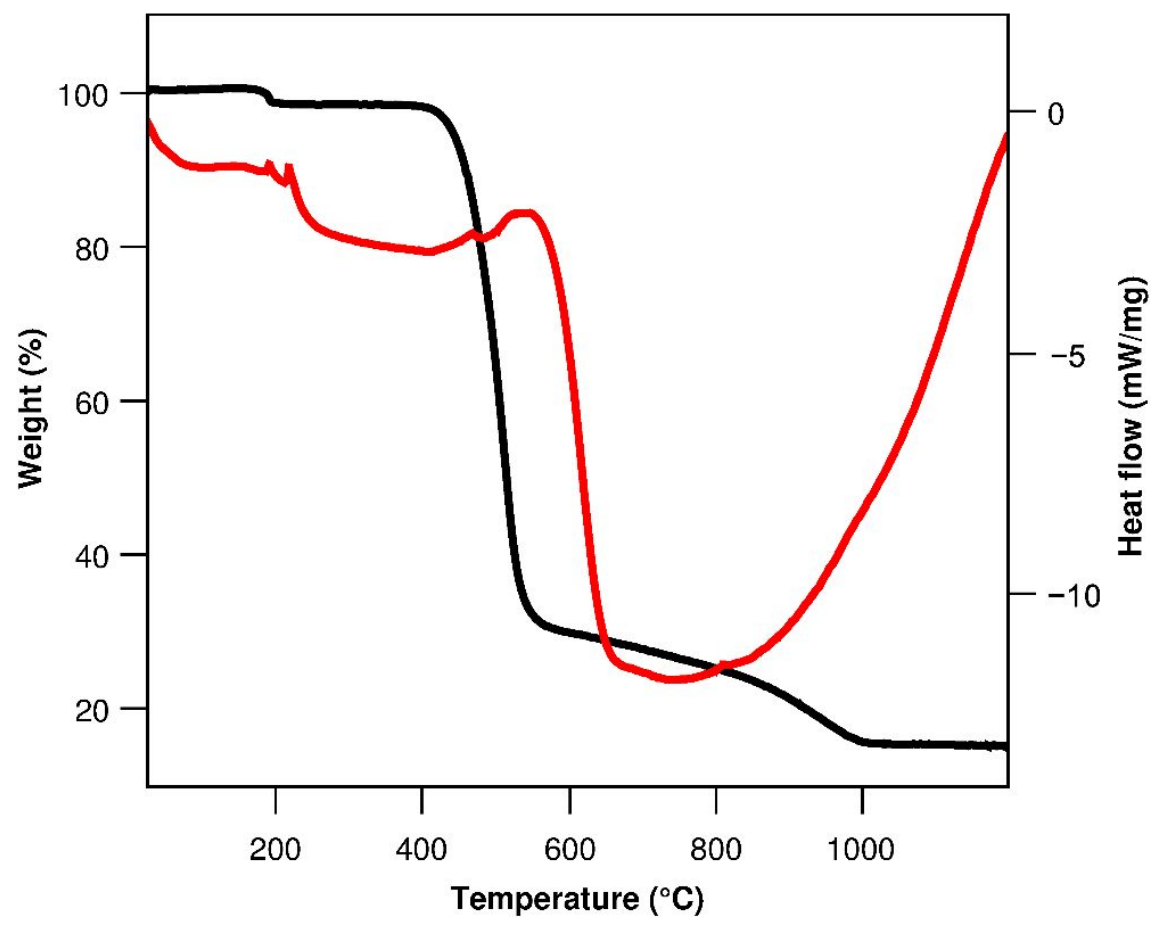

Figure S8. TGA and DSC of $\left[\mathrm{PPh}_{4}\right]_{2}\left[\mathrm{BiCu}_{2} \mathrm{I}_{7}\left(\mathrm{CH}_{3} \mathrm{CN}\right)\right](3)$. 
The thermal behavior of $\left[\mathrm{PPh}_{4}\right]_{2}\left[\mathrm{BiCu}_{2} \mathrm{I}_{7}\left(\mathrm{CH}_{3} \mathrm{CH}_{2} \mathrm{CN}\right)\right](4)(11.4 \mathrm{mg})$, was studied by TGA on a Netzsch STA $409 \mathrm{CD}$ from 25 to $1200^{\circ} \mathrm{C}$ with a heating rate of $10^{\circ} \mathrm{C} \mathrm{min}^{-1}$ in a constant flow

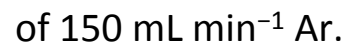

A mass loss of $3 \%$, corresponding to the loss of the propionitrile ligand, can be observed starting at $170{ }^{\circ} \mathrm{C}$, followed by a mass loss of $72 \%$ starting at $380{ }^{\circ} \mathrm{C}$. A third mass loss of $10 \%$ can be observed starting at $750{ }^{\circ} \mathrm{C}$.

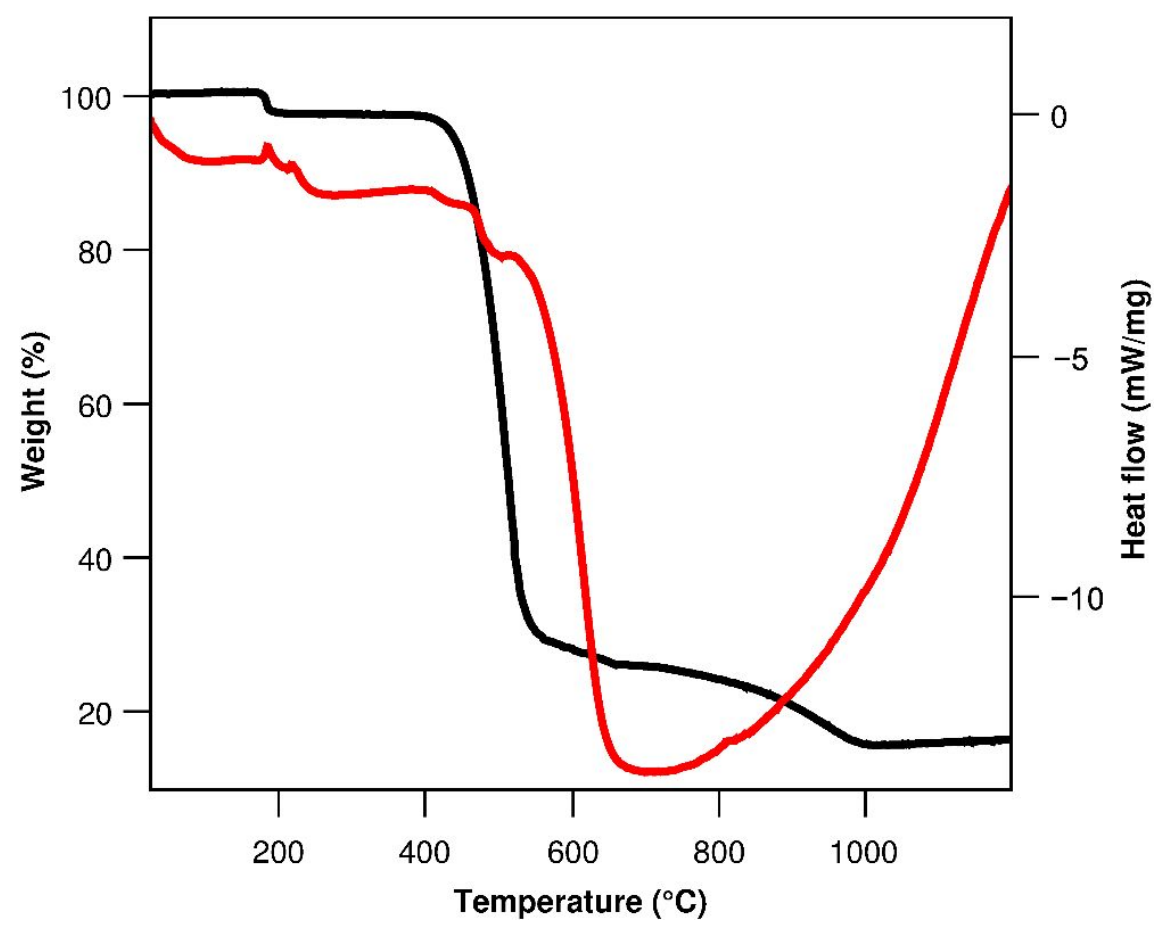

Figure S9. TGA and DSC of $\left[\mathrm{PPh}_{4}\right]_{2}\left[\mathrm{BiCu}_{2} \mathrm{l}_{7}\left(\mathrm{CH}_{3} \mathrm{CH}_{2} \mathrm{CN}\right)\right](4)$. 


\section{Powder diffraction}

Powder patterns were recorded on a STADI MP (STOE Darmstadt) powder diffractometer, with $\mathrm{CuK}_{\alpha 1}$ radiation with $\lambda=1.54056 \AA$ at room temperature in transmission mode. The patterns confirm the presence of the respective phase determined by SCXRD measurements and the absence of any major crystalline by-products.

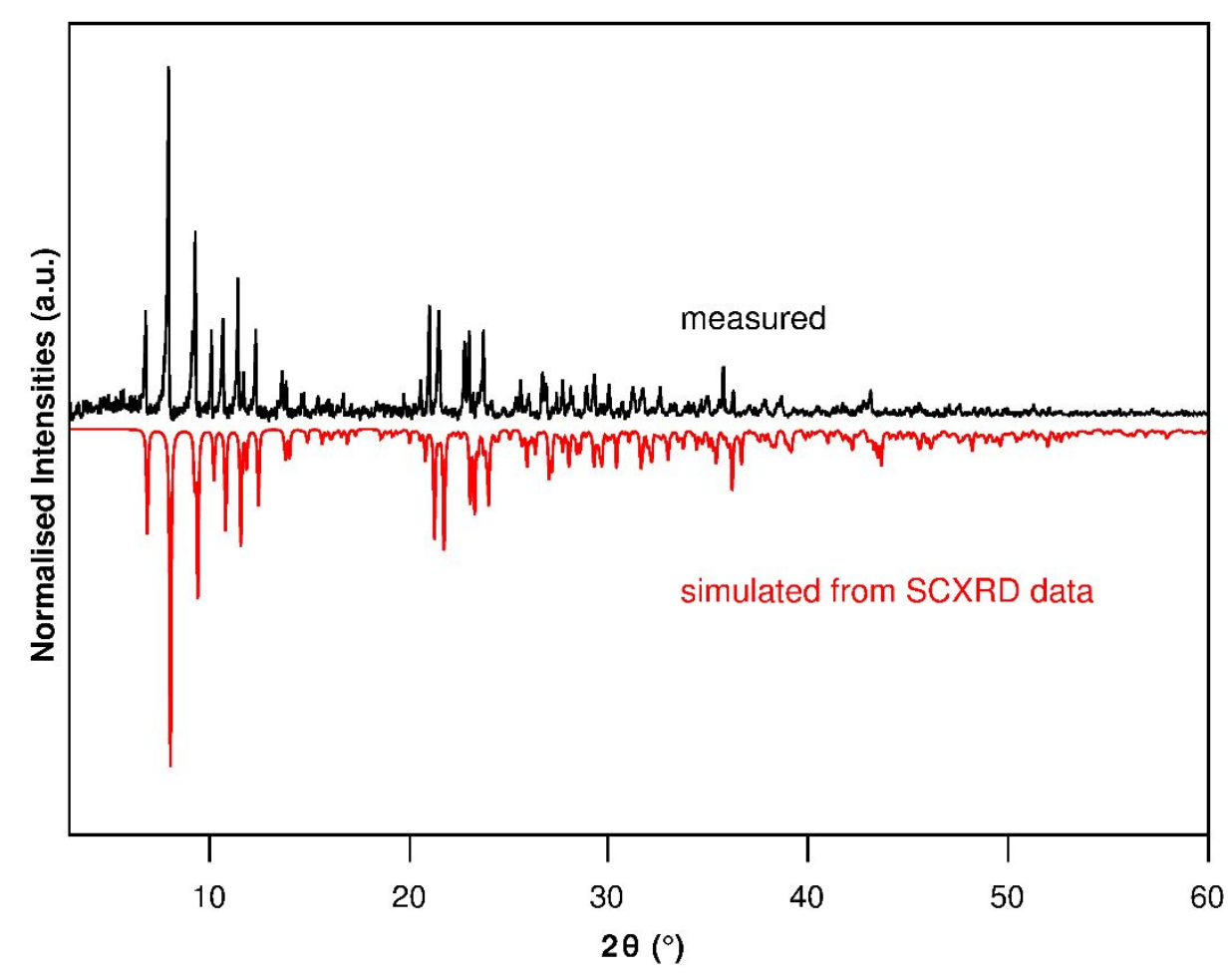

Figure S10. Powder diffraction pattern of $\left[\mathrm{PPh}_{4}\right]_{2}\left[\mathrm{SbCu}_{2} \mathrm{l}_{7}\left(\mathrm{CH}_{3} \mathrm{CN}\right)\right](\mathbf{1})$. 


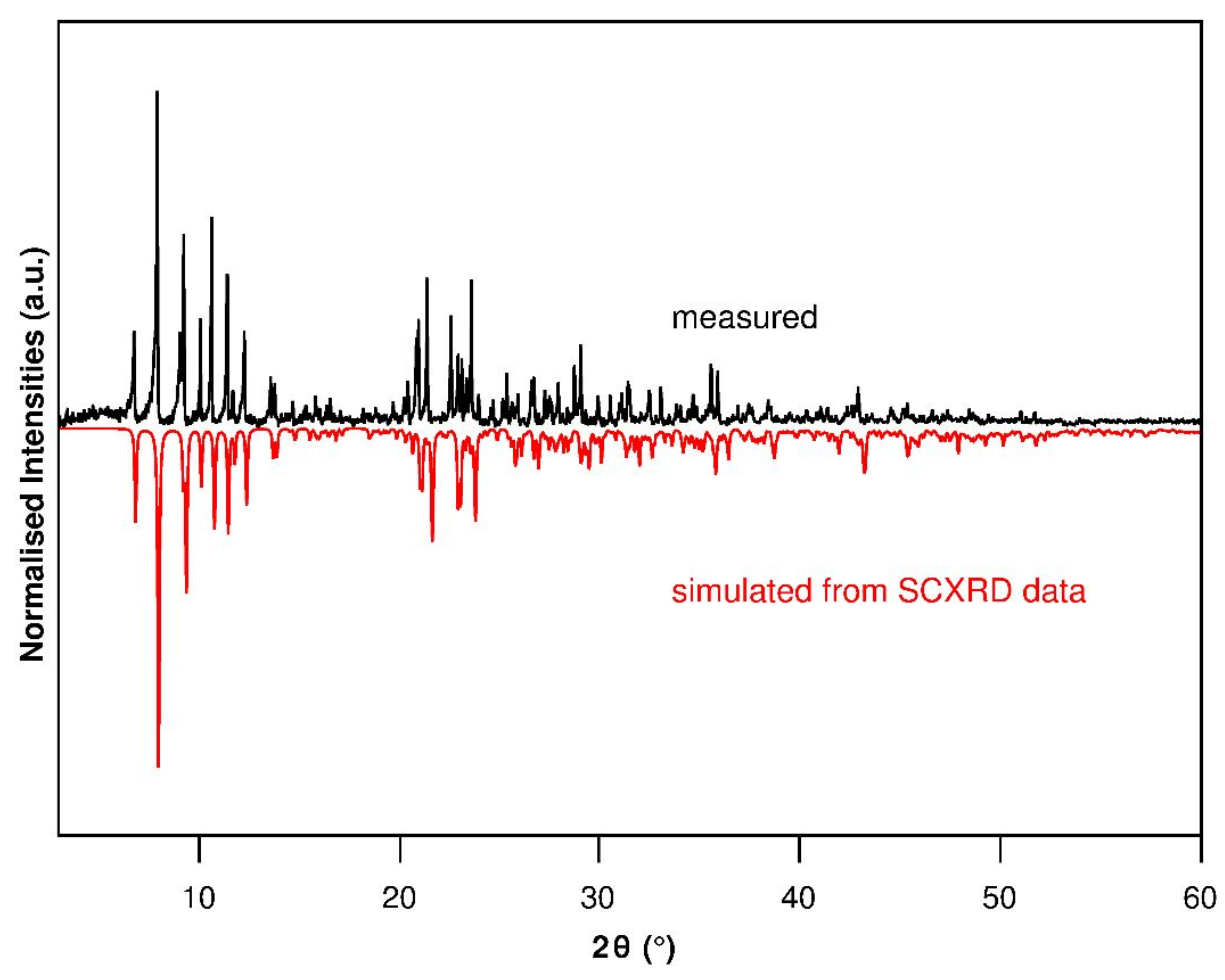

Figure S11. Powder diffraction pattern of $\left[\mathrm{PPh}_{4}\right]_{2}\left[\mathrm{SbCu}_{2} \mathrm{I}_{7}\left(\mathrm{CH}_{3} \mathrm{CH}_{2} \mathrm{CN}\right)\right]$ (2).

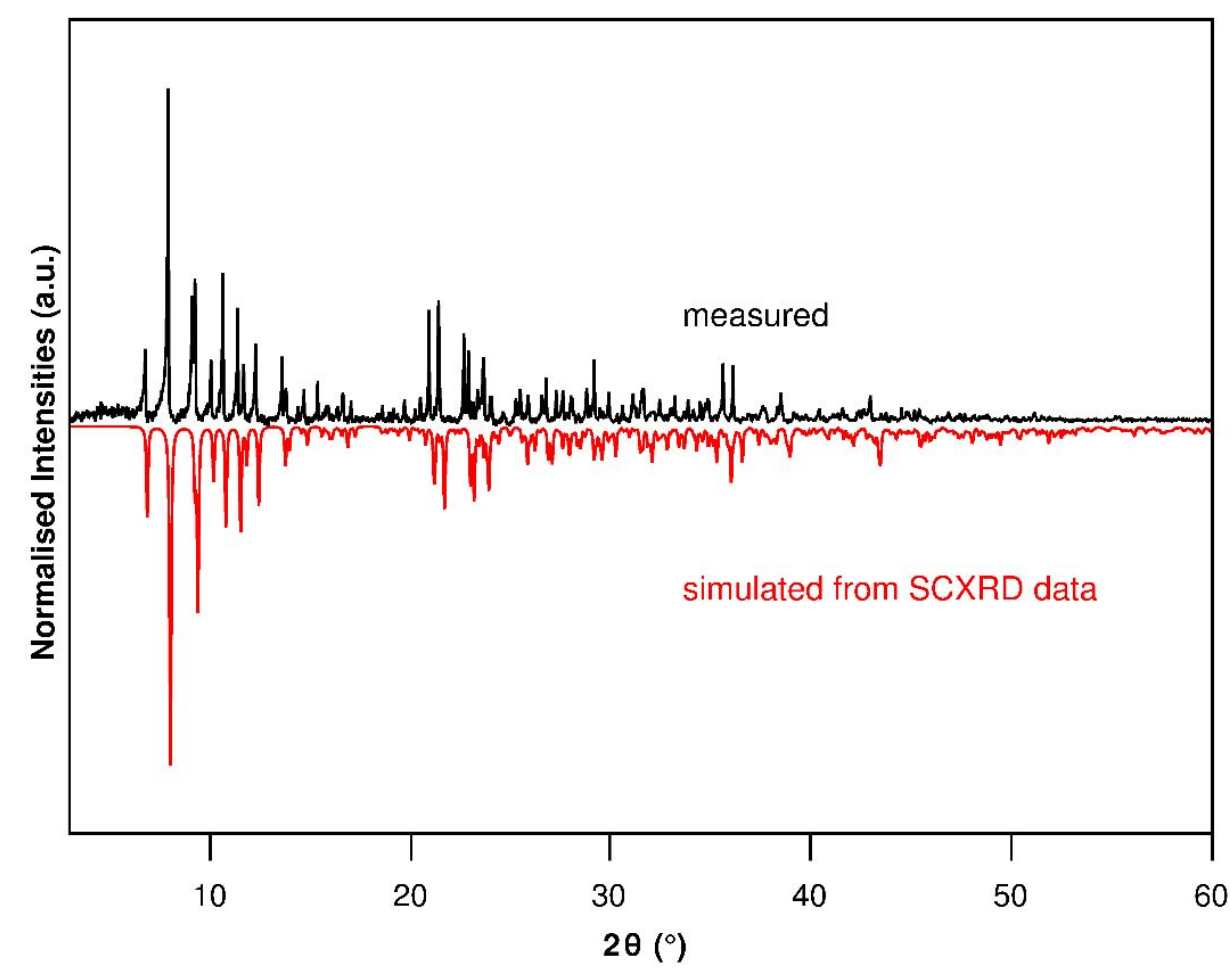

Figure S12. Powder diffraction pattern of $\left[\mathrm{PPh}_{4}\right]_{2}\left[\mathrm{BiCu}_{2} \mathrm{l}_{7}\left(\mathrm{CH}_{3} \mathrm{CN}\right)\right](3)$. 


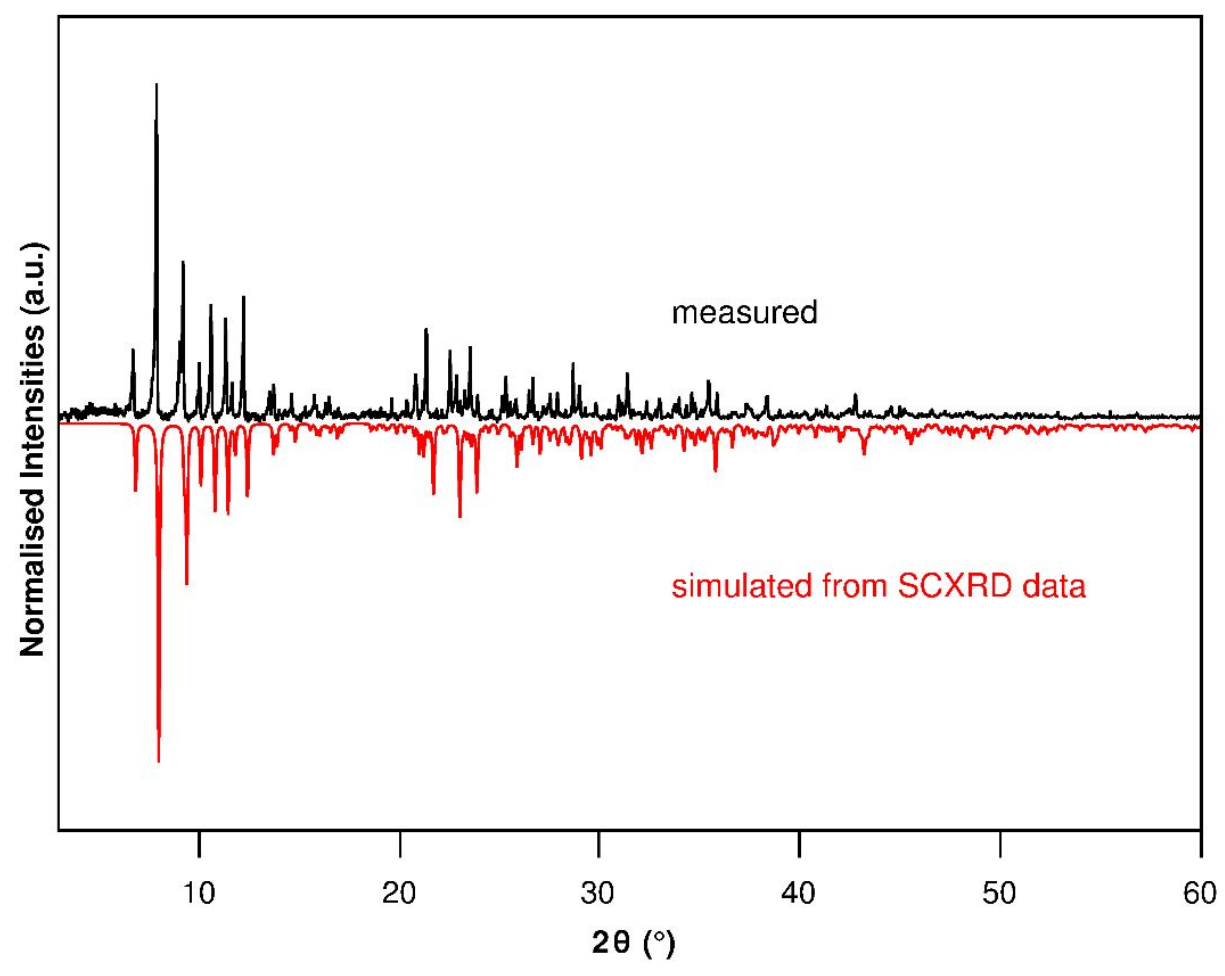

Figure S13. Powder diffraction pattern of $\left[\mathrm{PPh}_{4}\right]_{2}\left[\mathrm{BiCu}_{2} \mathrm{l}_{7}\left(\mathrm{CH}_{3} \mathrm{CH}_{2} \mathrm{CN}\right)\right](4)$. 


\section{IR spectroscopy}

IR spectra were recorded on a Bruker Tensor 37 FT-IR spectrometer equipped with an ATRPlatinum measuring unit. The typical peak pattern of the $\left[\mathrm{PPh}_{4}\right]^{+}$moiety can be identified between 500 and $1500 \mathrm{~cm}^{-1}$. ${ }^{1]}$

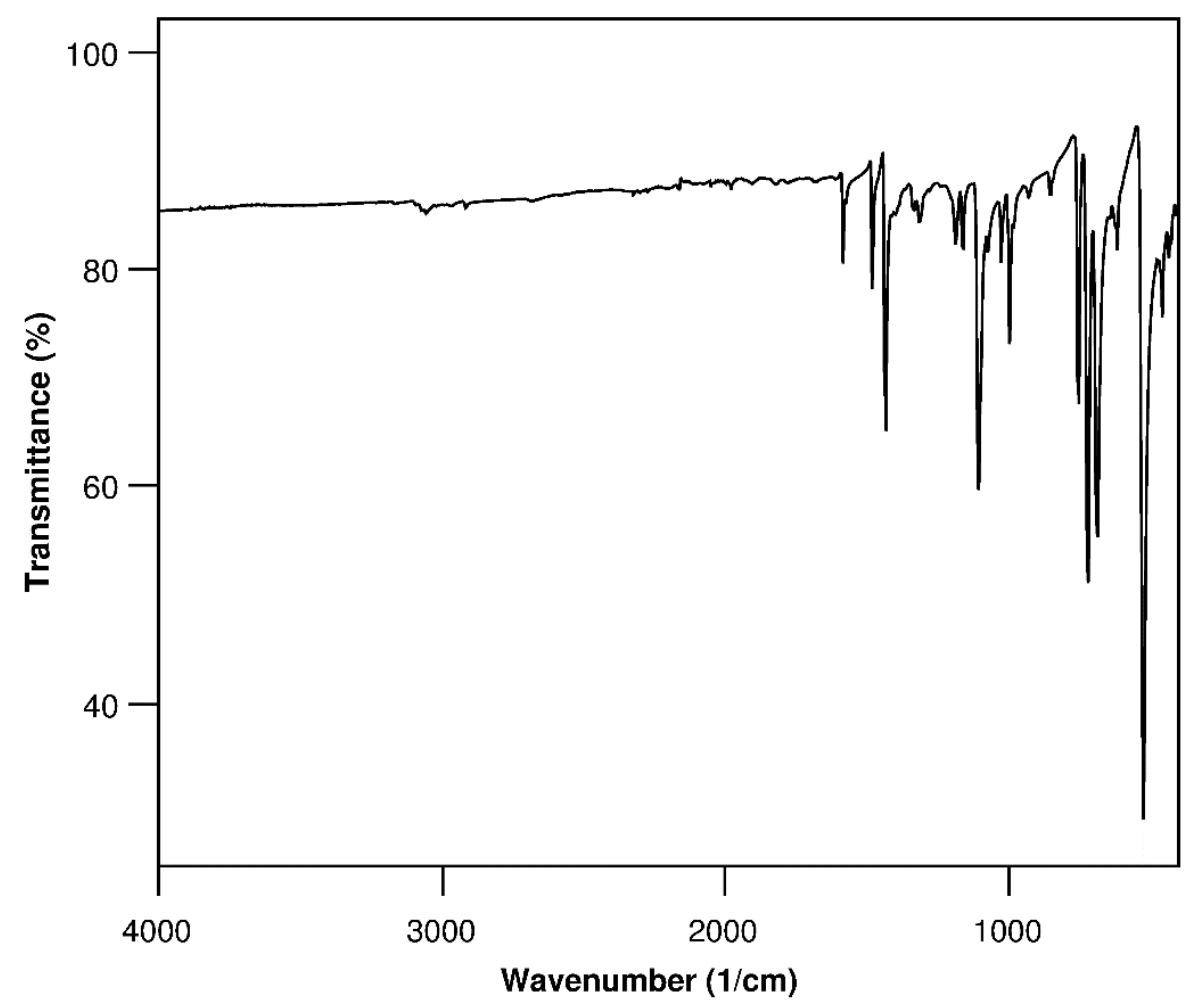

Figure S14. IR spectrum of $\left[\mathrm{PPh}_{4}\right]_{2}\left[\mathrm{SbCu}_{2} \mathrm{I}_{7}\left(\mathrm{CH}_{3} \mathrm{CN}\right)\right](1)$. 


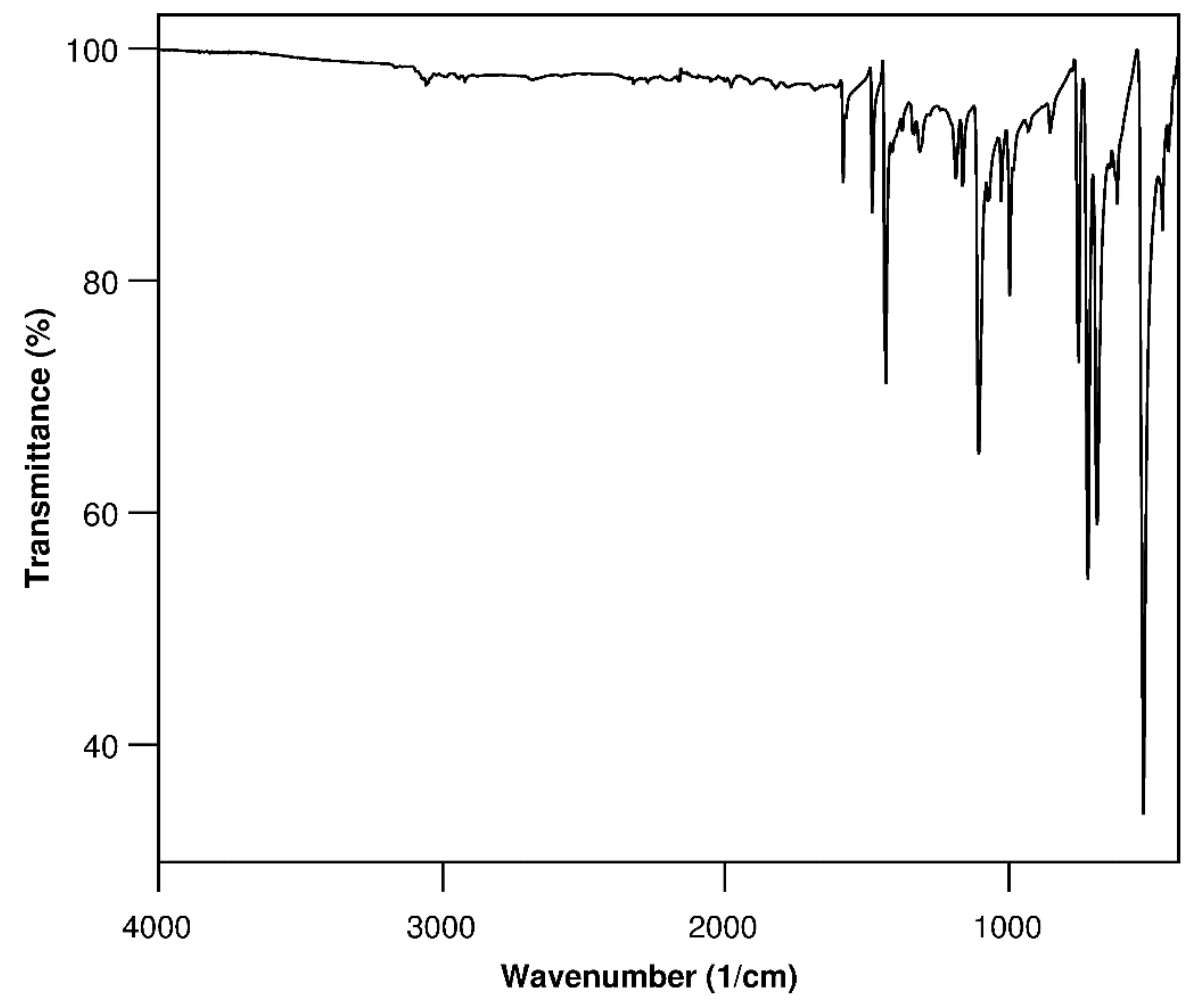

Figure S15. IR spectrum of $\left[\mathrm{PPh}_{4}\right]_{2}\left[\mathrm{SbCu}_{2} \mathrm{I}_{7}\left(\mathrm{CH}_{3} \mathrm{CH}_{2} \mathrm{CN}\right)\right]$ (2).

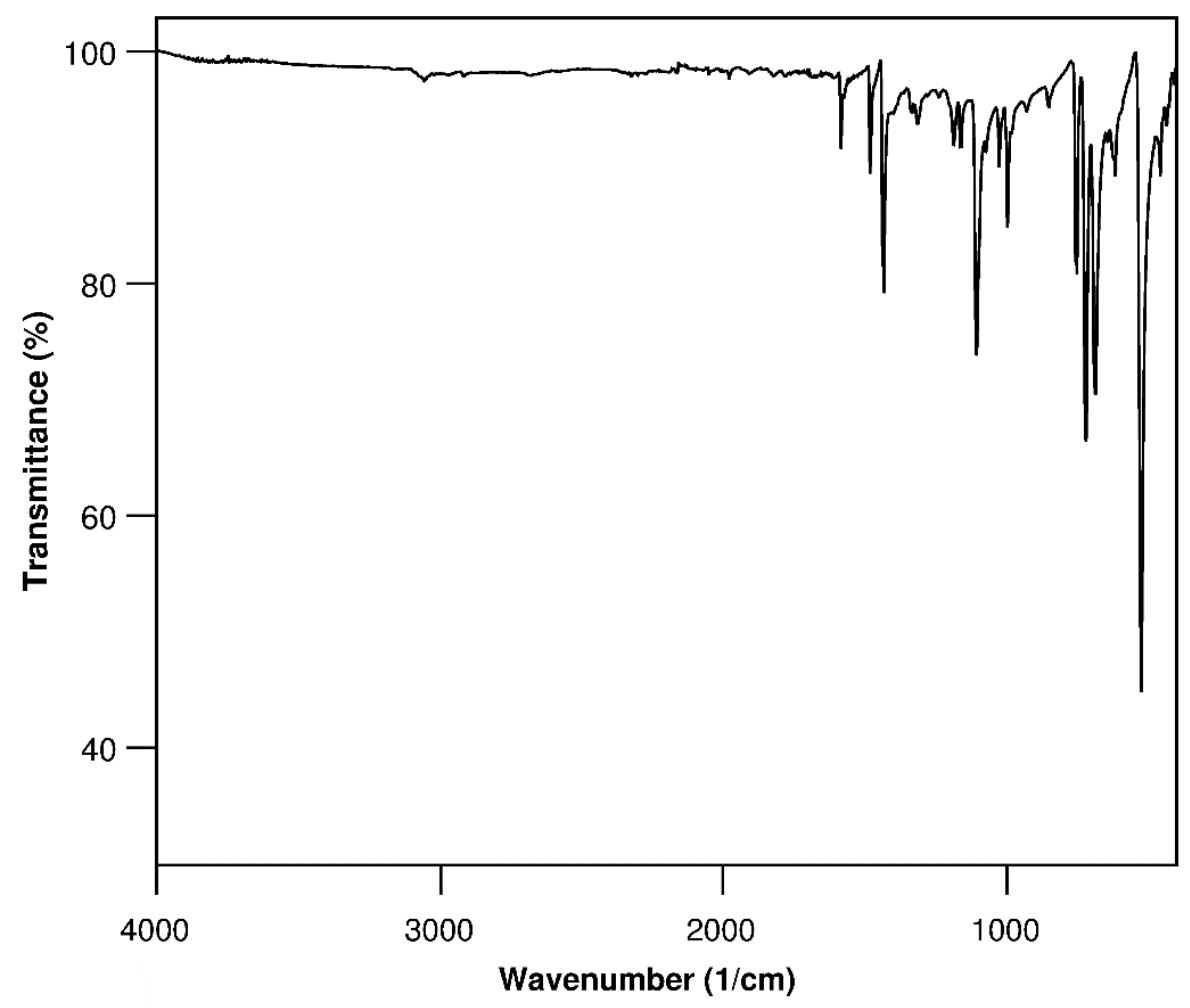

Figure S16. IR spectrum of $\left[\mathrm{PPh}_{4}\right]_{2}\left[\mathrm{BiCu}_{2} \mathrm{I}_{7}\left(\mathrm{CH}_{3} \mathrm{CN}\right)\right]$ (3). 


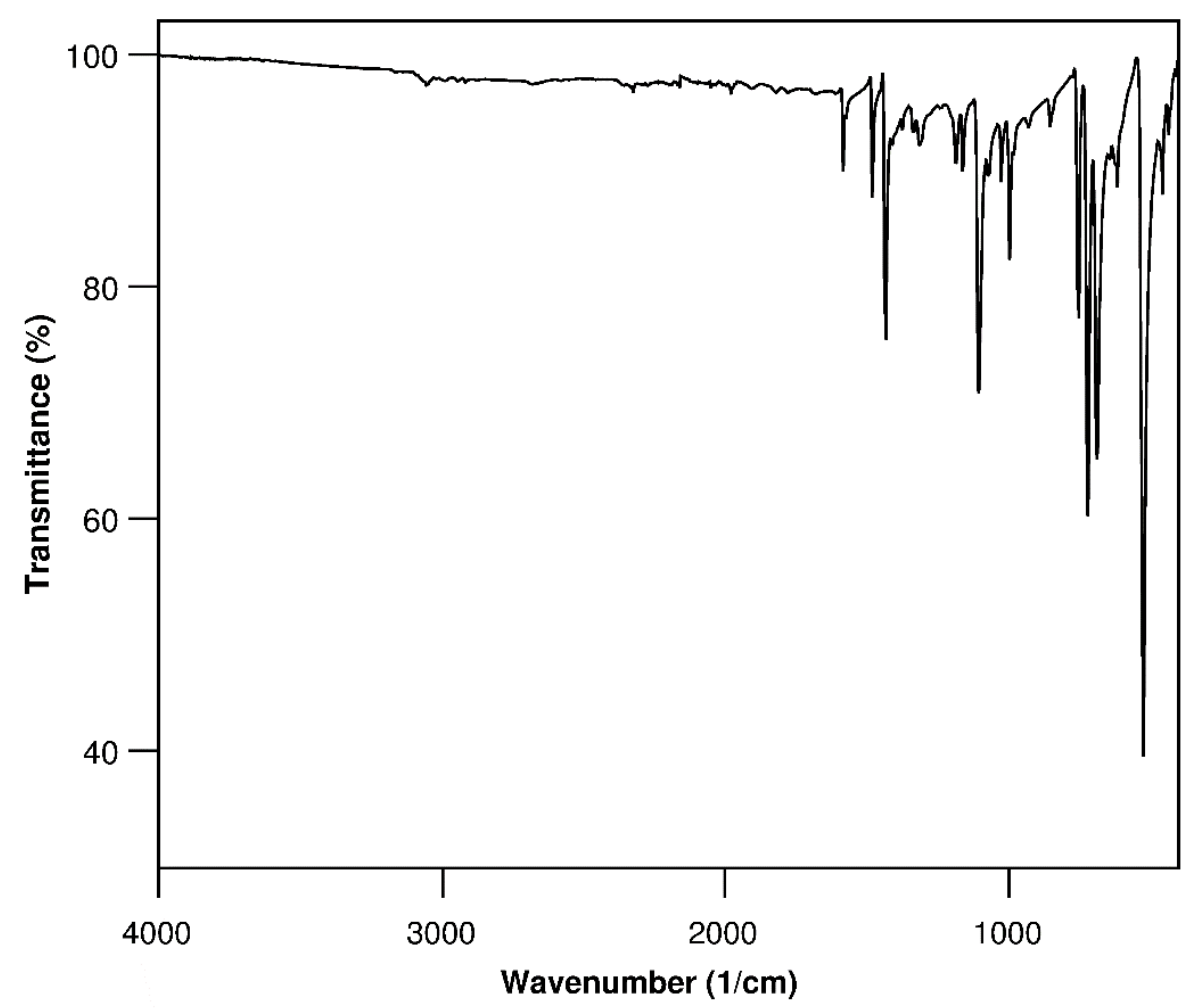

Figure S17. IR spectrum of $\left[\mathrm{PPh}_{4}\right]_{2}\left[\mathrm{BiCu}_{2} \mathrm{l}_{7}\left(\mathrm{CH}_{3} \mathrm{CH}_{2} \mathrm{CN}\right)\right]$ (4). 


\section{Synthesis and Characterization of Reference Compounds $\left[\mathrm{NH}_{2} \mathrm{Me}_{2}\right]_{3}\left[\mathrm{El}_{6}\right]$}

$\left[\mathrm{NH}_{2} \mathrm{Me}_{2}\right]_{3}\left[\mathrm{El}_{6}\right]$ reference compounds were synthesized from stoichiometric amounts of $\left[\mathrm{NH}_{2} \mathrm{Me}_{2}\right] \mathrm{l}$ and $\mathrm{El}_{3}$ in dry acetonitrile and identified from their PXRD patterns. The single crystal structure of $\left[\mathrm{NH}_{2} \mathrm{Me}_{2}\right]_{3}\left[\mathrm{Sbl}_{6}\right]$ has not been determined yet, but the recorded pattern shows that the compound is isomorphous to $\left[\mathrm{NH}_{2} \mathrm{Me}_{2}\right]_{3}\left[\mathrm{Bil}_{6}\right]^{[2]}$

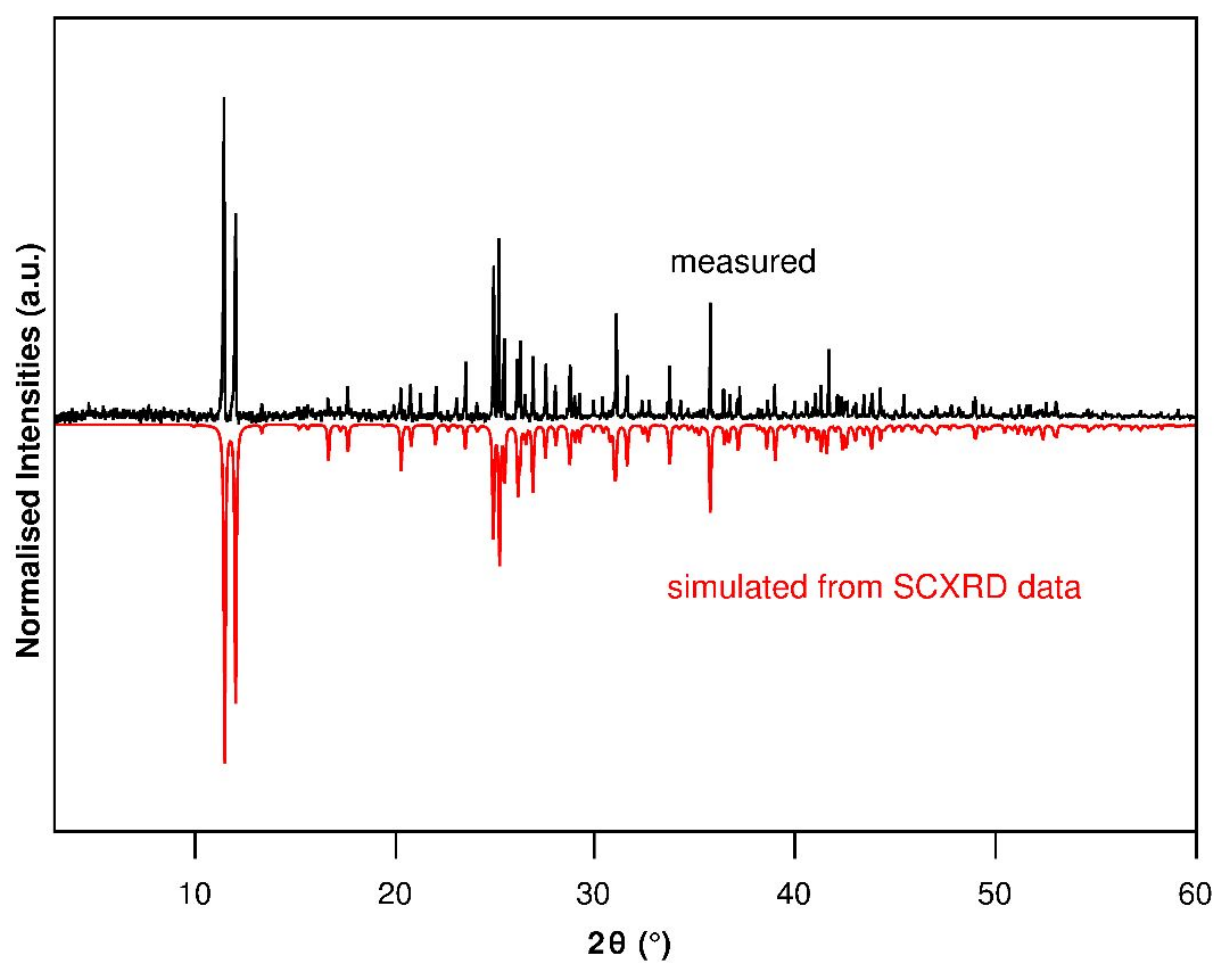

Figure S18. Powder diffraction pattern of $\left[\mathrm{NH}_{2} \mathrm{Me}_{2}\right]_{3}\left[\mathrm{Sbl}_{6}\right]$ and reference pattern from the literature. ${ }^{[2]}$ 


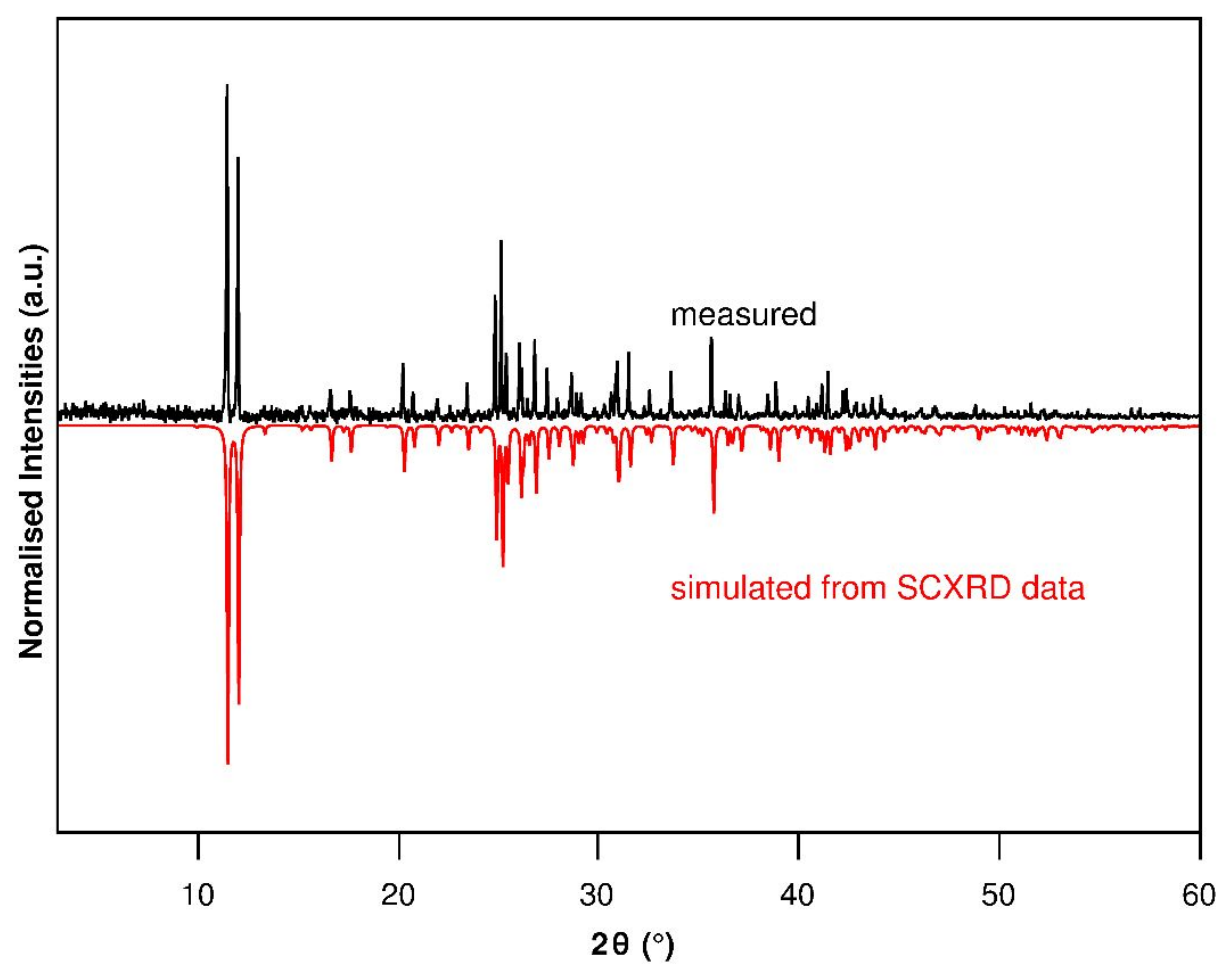

Figure S19. Powder diffraction pattern of $\left[\mathrm{NH}_{2} \mathrm{Me}_{2}\right]_{3}\left[\mathrm{Bil}_{6}\right]$ and reference pattern from the literature. ${ }^{[2]}$ 


\section{Mechanochemical Reactions}

The liquid assisted grinding process for $\left[\mathrm{PPh}_{4}\right]_{2}\left[\mathrm{SbCu}_{2} \mathrm{l}_{7}\left(\mathrm{CH}_{3} \mathrm{CN}\right)\right](1)$ is detailed below, 2-4 can be obtained in an identical fashion.
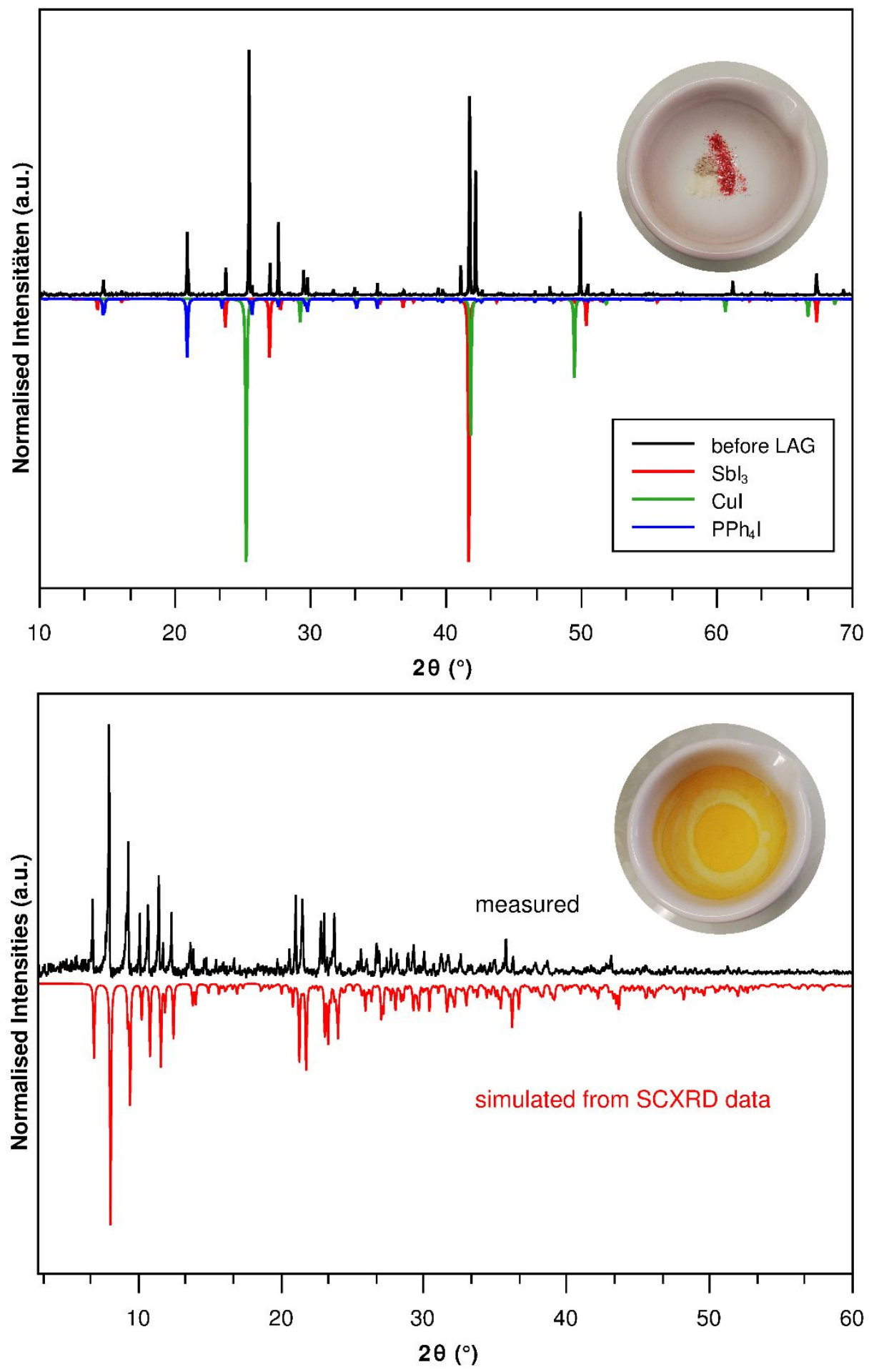

Figure S20. PXRD patterns before and after liquid assisted grinding of the reaction mixture for compound 1 with photographs of the reaction shown as insets. 


\section{Photoluminescence spectroscopy}

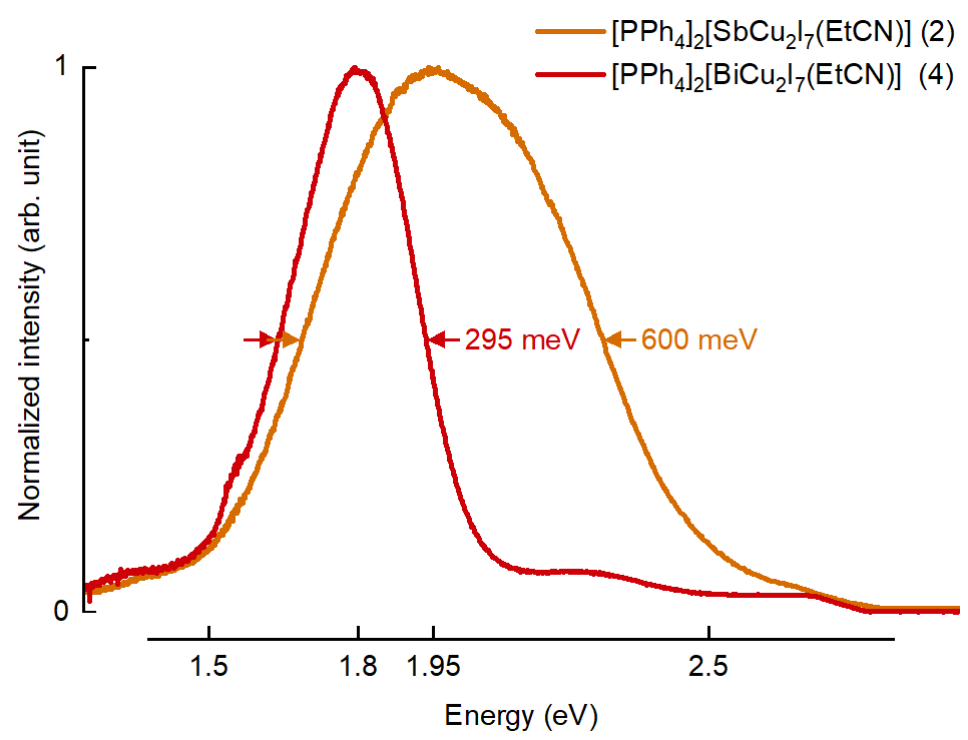

Figure S21. Normalized low temperature photoluminescence spectra of the antimonate $\mathbf{2}$ and bismuthate 4 (orange and red lines) at $10 \mathrm{~K}$.

\section{References}

[1] Wittig, G.; Benz, E. Über das Verhalten von Dehydrobenzol gegenüber nucleophilen und elektrophilen Reagenzien. Chem. Ber. 1959, 92, 1999-2013.

[2] Lindsjö, M.; Fischer, A.; Kloo, L. Anionic Diversity in lodobismuthate Chemistry. Z. Anorg. Allg. Chem. 2005, 631, 1497-1501. 